\title{
A Case of Langerhans Cell Sarcoma Presenting as Submandibular Gland Mass
}

\author{
Geonho Lee ${ }^{\mathbb{D}}$, Kunho Song, Ki Wan Park, and Bon Seok Koo ${ }^{\mathbb{D}}$ \\ Department of Otorhinolaryngology-Head and Neck Surgery, School of Medicine, Chungnam National University, Daejeon, Korea
}

\author{
악하선 종물로 나타난 랑게르한스세포 육종 1예 \\ 이건호 · 송근호 · 박기완 · 구본석 \\ 충남대학교 의과대학 이비인후-두경부외과학교실
}

\author{
Received September 14, 2018 \\ Revised October 5, 2018 \\ Accepted October 16, 2018 \\ Address for correspondence \\ Bon Seok Koo, MD, PhD \\ Department of Otorhinolaryngology- \\ Head and Neck Surgery, \\ School of Medicine, \\ Chungnam National University, \\ 282 Munhwa-ro, Jung-gu, \\ Daejeon 35015, Korea \\ Tel $+82-42-280-7695$ \\ Fax $+82-42-253-4059$ \\ E-mail bskoo515@cnuh.co.kr
}

Langerhans cell sarcoma is a rare, proliferative tumor of Langerhans cells, which shows cytologic characteristics and clinical features of malignant tumor. Langerhans cell sarcoma primarily occurs in lymph nodes, skin, lung, liver, and spleen. However, very few cases have been reported in the head and neck region. Because of its rarity, an optimal treatment approach is unknown; however, Langerhans cell sarcoma grows aggressively and shows a poor prognosis, such that a more aggressive and multi-modality treatment approach is necessary. Here, we report the case of a 36-year-old male with Langerhans cell sarcoma, who presented with a mass in the submandibular gland area and was treated with wide excision and postoperative radiotherapy. Korean J Otorhinolaryngol-Head Neck Surg 2019;62(9):520-3

Key Words Langerhans cells · Sarcoma · Treatment.

\section{서 론}

랑게르한스세포 종양은 세계보건기구(WHO)에서 랑게르 한스세포 조직구증(Langerhans cell histiocytosis)과 랑게 르한스세포 육종(Langerhans cell sarcoma)으로 분류하였 다.1) 랑게르한스세포 조직구증은 대개 국한성이며 양성으로 좋은 예후를 보이지만, 드물게 랑게르한스세포 육종으로 전 환될 수 있음이 보고된 바 있다. ${ }^{2)}$ 반면에 랑게르한스세포 육 종은 급속히 성장하며 국소적 침범, 재발 및 전이될 수 있는 악성종양으로 나쁜 예후를 보인다고 알려져 있다. 랑게르한 스세포 육종은 극히 드문 질환으로, 국내에서 보고된 경우 는 많지 않다. 저자들은 좌측 악하선 부위에 발생한 종물을 주소로 내원한 36세 남자 환자에서 랑게르한스세포 육종으

This is an Open Access article distributed under the terms of the Creative Commons Attribution Non-Commercial License (https://creativecommons.org/licenses/by-nc/4.0) which permits unrestricted non-commercial use, distribution, and reproduction in any medium, provided the original work is properly cited.
로 진단된 증례를 경험하였기에 문헌 고찰과 함께 보고하고 자 한다.

\section{증 례}

36세 남자가 6개월 전 발견된 좌측 악하선 부위의 종물을 주소로 내원하였다. 종물의 크기는 약 $2 \times 2 \mathrm{~cm}$ 였으며 단단 한 무통성 가동성 종물로 피부를 직접 침범하는 모습이었다 (Fig. 1). 구강 및 인후두의 이학적 검사에서 다른 이상은 없 었으며, 10년 전 폐결핵으로 항결핵제 치료를 받았던 기왕력 이외에 다른 질환은 없었다. 악성 병변을 의심하여 시행한 세 침 흡인 세포 검사에서 일부 화농성 변화와 함께 심한 이형 성을 보이는 악성종양으로 진단되었으며, 경부 CT 및 MRI에 서 좌측 악하선 부위에 $2.5 \mathrm{~cm}$ 크기의 불균질하게 조영 증 강되는 침윤성 종물이 관찰되었고, 주변의 염증이 동반되어 있었다(Fig. 2). 수술 전 검사에서 명확한 원발 부위는 알 수 
없었으나 악하선과 피부를 침범하는 악성종양으로 판단하 여, 종물에서 $1 \mathrm{~cm}$ 이상의 경계를 두고 악하선과 침범된 피 부 및 주변 림프절을 포함하여 광범위절제를 시행하였고, 안 면 신경의 하악지는 희생시켰으며 혀밑 신경 및 혀 신경은 보 존하였다. 결손된 피부는 성형외과에서 회전 피판술을 이용 하여 재건하였다. 수술 후 병리조직학적 검사는 면역조직화 학염색에서 $\mathrm{CDla}$ 에 양성을 보이고 이형성 및 증가된 유사분 열활성도를 보이며 괴사된 세포를 포함하는 등 악성 세포학 적인 특성을 갖고 있는 랑게르한스세포 육종으로 진단되었 고, 악하선과 주변 림프절 및 절제연의 침범은 없었으며 병리 조직 검토 결과 연조직에서 기원한 것으로 판정되었다(Fig. 3). 병기 설정을 위한 PET-CT에서 원격전이가 의심되는 병 변은 없었다. 랑게르한스세포 육종은 고등급 육종으로 예후 가 나쁜 것으로 알려져 있기에 수술 후 보조 치료로 방사선치

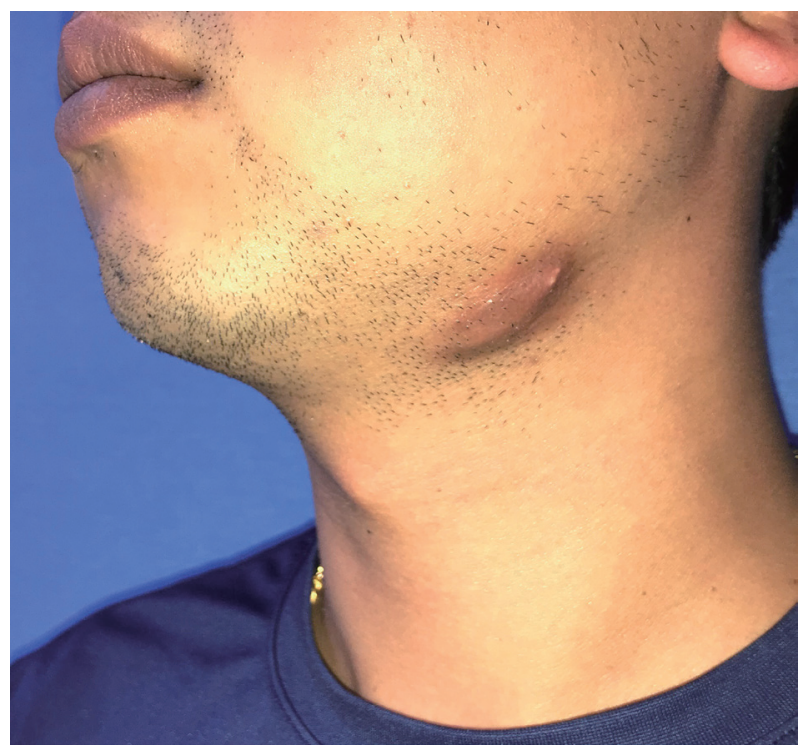

Fig. 1. Gross image. Left submandibular gland mass invading the skin.
료를 계획하였다. 원발병소에 30회에 걸쳐서 총 $6000 \mathrm{cGy}$ 의 방사선 치료를 시행한 이후 9 개월이 경과한 현재까지 재발의 증거 없이 외래 추적 관찰 중이다.

\section{고 찰}

랑게르한스세포(Langerhans cell)는 조직구(histiocyte) 계 통의 일부로 항원제시세포(antigen-presenting cell)로 작용 하며 점막의 상부 기저층(supra-basal layer), 진피, 림프절 및 흥선 등에서 발견된다. 면역조직화학적으로 CDla, S-100과 랑게린(langerin)에 양성을 보이고, 전자현미경에서 버벡과립 (Birbeck granules)을 확인함으로써 구별할 수 있다. 랑게르 한스세포 육종은 1984년 Wood 등ㄱㅇㅔ 의해서 처음 보고된 질 환으로, 현재까지도 매우 드문 질환이며 정확한 발생률은 아 직까지 잘 알려져 있지 않다. 랑게르한스세포 육종은 이형성 (atypia), 과다염색핵(hyperchromatic nuclei), 증가된 유사 분열상(mitotic figure)등의 세포학적으로 악성의 형태를 보 이는 것으로 랑게르한스세포 조직구증과 구별되며, 발병기전 으로는 새로이(de novo) 발병하거나, 랑게르한스세포 조직구 증으로부터 진행하여 발병할 수 있음이 보고되었다. ${ }^{4)}$ 가장 흔한 원발 부위는 림프절, 피부로 보고되고 있고, 폐, 뼈, 간 및 비장 등에서도 발견되었다고 보고된다. ${ }^{4-9)}$ 침범 부위에 따 라 다양한 임상 양상을 나타내고, 빠르게 성장하여 공격적 으로 진행하는 특성을 보이며 예후가 나쁘다. 원인은 면역억 제상태, 바이러스, 기존의 혈액학적인 질환과 관련되어 있다 고 보고된다. ${ }^{2,10-13)}$

Howard 등헤에 의한 체계적 고찰(systemic review)에서 단 일 부위에 국한된 경우(local disease)는 $33.3 \%$, 국소지역 침범 된 경우(locoregional involvement)는 $25.8 \%$, 파종성 질환 (disseminated disease)은 $40.9 \%$ 를 차지했다. 랑게르한스세

Fig. 2. Preoperative neck CT findings. Infiltrative heterogeneously enhancing soft tissue lesion (about $2.5 \mathrm{~cm}$ in size) in the left submandibular gland with surrounding inflammation, Axial view (A). Coronal view (B).
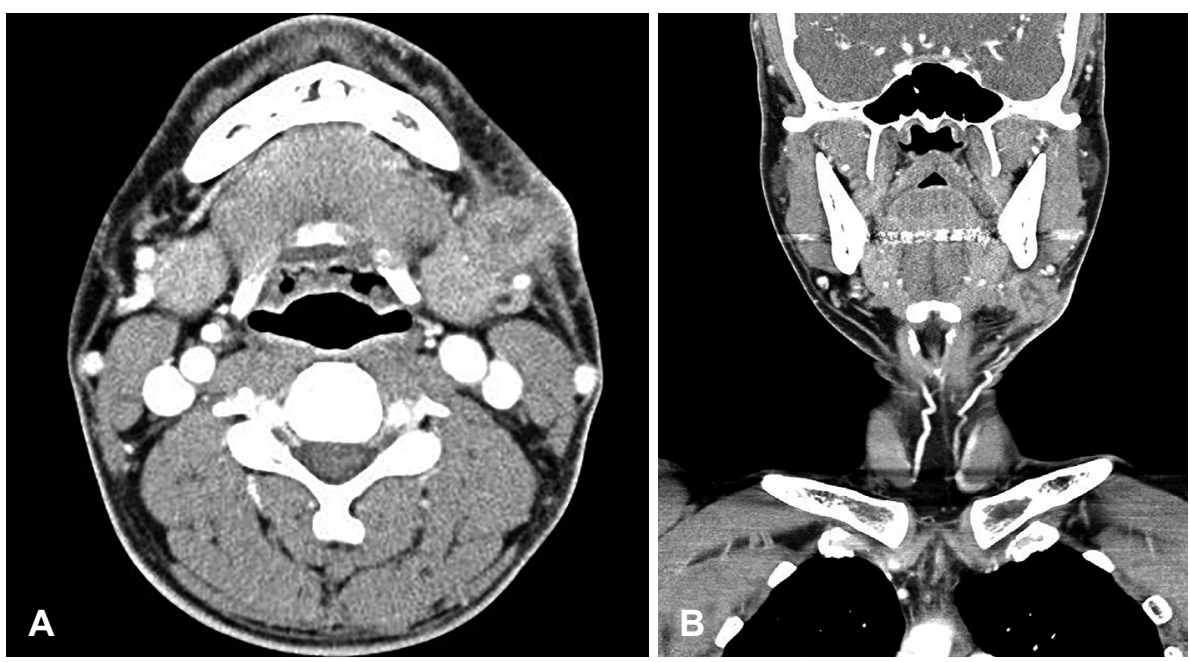
포 육종은 아직 표준화된 치료법이 없으며, 치료에 대한 반 응 및 예후도 다양하게 보고되고 있다. ${ }^{5,6,8,9)}$ 단일 부위 혹은 국소지역에 국한된 질환은 수술을 먼저 고려할 수 있고, 깨 끗한 절제연을 확보할 수 있다면 수술이 효과적인 치료라고
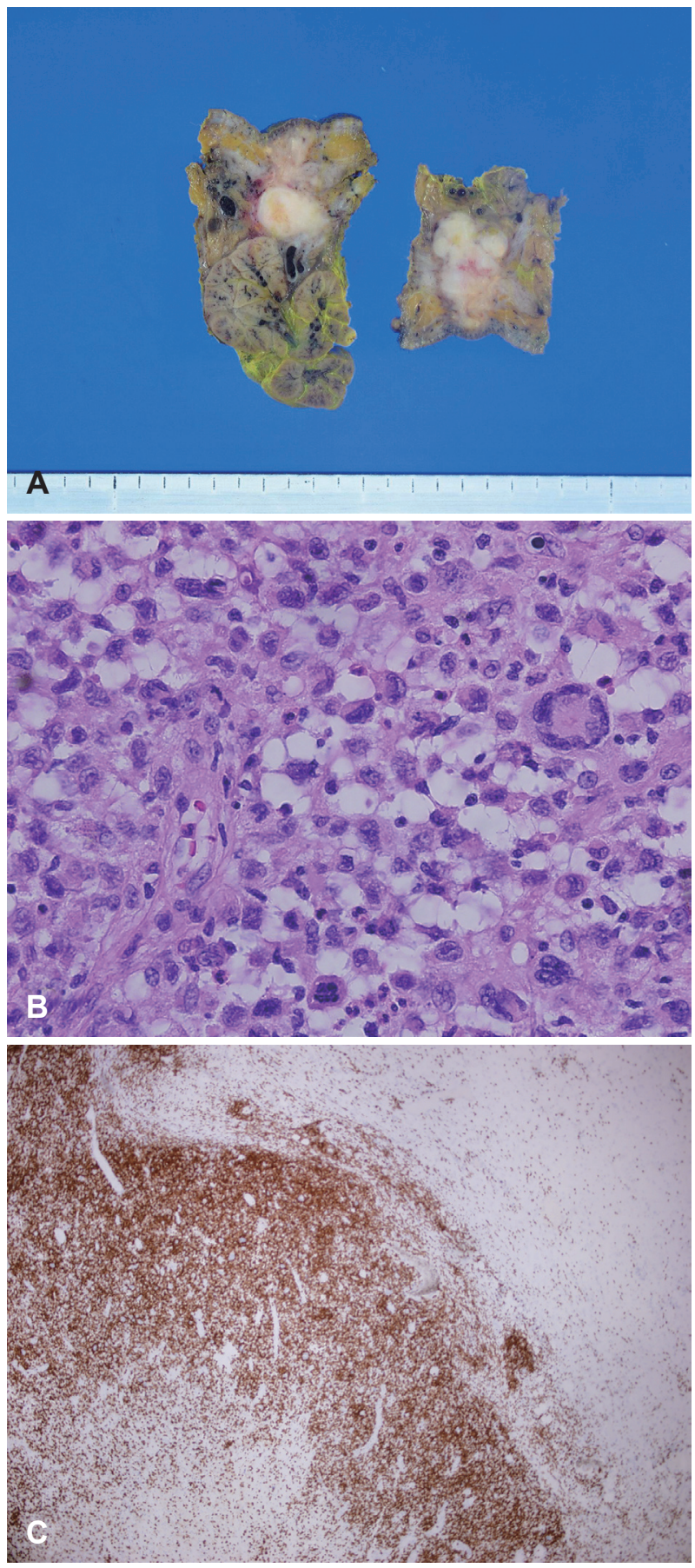

Fig. 3. Postoperative specimen gross findings. Relatively well-defined, irregular and solid mass was observed, measuring $2.5 \times 0.9$ $\mathrm{cm}$ in size (A). Pathologic findings. The tumor cells showed malignant cytological features. Cellular atypia, multinucleated giant cell, increased mitotic activity and focal necrosis were observed (H\&E staining, $\times 400)(B)$. Immunohistochemical staining for CD1a was positive $(\times 40)(C)$. H\&E : hematoxylin-eosin
보고된다. 랑게르한스세포 육종의 수술 범위에 대해서는 일 치된 견해가 없으나 조직학적으로 림프절 전이를 확진하여 추 후의 보조 요법 등의 치료를 통해 재발을 방지하고 완전관해 를 달성하기 위해서는 선택적 경부절제술을 수술 범위에 포함 하는 것이 추천된다. ${ }^{6)}$ 절제연 양성 혹은 근접 절제연, 면역저 하 상태이거나 다른 혈액학적인 질환이 동반된 경우에는 보조 요법으로 방사선치료나 항암화학치료를 추가할 수 있다. 파종 성 질환은 수술과 함께 항암화학치료 혹은 방사선항암화학 치료를 병행하며, 수술이 불가능한 경우에는 항암화학치료 혹은 방사선항암화학치료를 시행하고 치료에 반응이 없거나 재발한 경우에는 골수이식을 고려할 수 있다. 적극적인 치료 에도 불구하고, 랑게르한스세포 육종의 총체적인 1 년 질병 특이 생존율(overall 1-year disease specific survival)은 58\% 정도이며, 총체적인 5 년 질병 특이 생존율은 $12 \%$ 정도로 예 후가 매우 나쁜 것으로 보고되고 있다. 단일 부위에 국한된 경우는 치료 방법에 상관없이 치료에 대한 반응이 좋은 편이 며, 5년 질병 특이 생존율은 $61 \%$ 정도로 보고된다. 국소지역 침범된 경우에 수술과 함께 보조 항암화학요법을 추가하는 것이 단독 항암화학치료에 비해 반응이 좋은 것으로 알려져 있으며, 5 년 질병 특이 생존율은 $24 \%$ 정도로 보고된다. ${ }^{5,6)}$ 문 헌 고찰을 통해 알아본 랑게르한스세포 육종의 치료는 주로 수술 혹은 항암화학치료를 중심으로 이뤼졌으며, 방사선치 료를 일차 치료로 이용한 경우는 거의 없었으나 Nakayama 등ㄱ은 경부 림프절에 국한된 랑게르한스세포 육종에서 방사 선치료 단독으로 완전관해를 보였다고 보고했다. 파종성 질 환은 1 년 이내에 대부분 사망했지만, 항암화학치료 후에 골 수이식을 시행한 환자들에서 완전관해를 보였다는 보고가 있어서 파종성 질환에서 유일하게 신뢰할 만한 치료로 생각 된다. ${ }^{13,14)}$ 본 증례의 경우에는 단일 부위에 국한된 질환이었지 만, 이 질환의 공격적인 특성 및 나쁜 예후, 젊은 나이인 환자 의 기대여명을 고려했을 때 적극적인 치료를 위해 보조 요법 으로 방사선치료를 추가했으며, 현재까지 중대한 합병증이나 재발의 증거 없이 지속적으로 추적 관찰 중이다.

Chen 등미은 랑게르한스세포 육종에서 BRAF V600E 돌연 변이가 발현됨을 보고하였고, Mourah 등 ${ }^{15)}$ 은 BRAF 돌연변이 를 보이는 랑게르한스세포 육종 환자에서 dabrafenib을 사용 하여 완전관해에 이른 증례를 보고하였다. 랑게르한스세포 육종에서 특이적이지는 않지만, 추후의 연구를 통해서 BRAF 돌연변이를 활용할 수 있을 것으로 생각되며, vemurafenib, dabrafenib 같은 특이적인 단클론항체(monoclonal antibody) 를 다른 치료에 반응하지 않는 랑게르한스세포 육종에서 대 안적인 치료로 고려할 수 있을 것으로 생각된다.

랑게르한스세포 육종은 매우 드물고 국내에서는 거의 보 
고된 바가 없는 드문 질환으로 아직 정립된 치료방법이 없으 나 진단 당시에 다양한 치료를 적극적으로 고려하는 것이 재 발을 예방하고 생존율을 높이는 방법이라고 생각되며, 치료 이후에도 주의 깊은 추적 관찰이 필요하다. 앞으로 더 많은 증례가 보고된다면 예후가 나쁜 것으로 알려진 랑게르한스 세포 육종에 대해 더 잘 이해할 수 있게 되고 적절한 치료방 법에 대한 논의도 이루어질 수 있을 것으로 생각한다.

\section{ORCID}

Bon Seok Koo

https://orcid.org/0000-0002-5928-0006

Geonho Lee https://orcid.org/0000-0002-9531-1471

\section{REFERENCES}

1) Swerdlow SH, Campo E, Pileri SA, Harris NL, Stein H, Siebert R, et al. The 2016 revision of the World Health Organization classification of lymphoid neoplasms. Blood 2016;127(20):2375-90.

2) Lee JS, Ko GH, Kim HC, Jang IS, Jeon KN, Lee JH. Langerhans cell sarcoma arising from Langerhans cell histiocytosis: A case report. J Korean Med Sci 2006;21(3):577-80.

3) Wood C, Wood GS, Deneau DG, Oseroff A, Beckstead JH, Malin J. Malignant histiocytosis X. Report of a rapidly fatal case in an elderly man. Cancer 1984;54(2):347-52.

4) Nakamine H, Yamakawa M, Yoshino T, Fukumoto T, Enomoto $Y$, Matsumura I. Langerhans cell histiocytosis and Langerhans cell sarcoma: Current understanding and differential diagnosis. J Clin Exp Hematop 2016;56(2):109-18.

5) Howard JE, Dwivedi RC, Masterson L, Jani P. Langerhans cell sarcoma: A systematic review. Cancer Treat Rev 2015;41(4):320-31.
6) Howard JE, Masterson L, Dwivedi RC, Jani P. Langerhans cell sarcoma of the head and neck. Crit Rev Oncol Hematol 2016;99:180-8.

7) Nakayama M, Takahashi K, Hori M, Okumura T, Saito M, Yamakawa $\mathrm{M}$, et al. Langerhans cell sarcoma of the cervical lymph node: A case report and literature review. Auris Nasus Larynx 2010;37(6): 750-3.

8) Wang YN, Zhou XG, Wang Z. Langerhans cell sarcoma in the cervical lymph node: A case report and literature review. Acta Haematol 2013; 129(2):114-20.

9) Zwerdling T, Won E, Shane L, Javahara R, Jaffe R. Langerhans cell sarcoma: Case report and review of world literature. J Pediatr Hematol Oncol 2014;36(6):419-25.

10) Chen W, Jaffe R, Zhang L, Hill C, Block AM, Sait S, et al. Langerhans cell sarcoma arising from chronic lymphocytic lymphoma/small lymphocytic leukemia: Lineage analysis and BRAF V600E mutation study. N Am J Med Sci 2013;5(6):386-91.

11) Murakami I, Matsushita M, Iwasaki $T$, Kuwamoto $S$, Kato M, Horie $\mathrm{Y}$, et al. High viral load of Merkel cell polyomavirus DNA sequences in Langerhans cell sarcoma tissues. Infect Agent Cancer 2014;9:15.

12) Murakami I, Wada N, Nakashima J, Iguchi M, Toi M, Hashida Y, et al. Merkel cell polyomavirus and Langerhans cell neoplasm. Cell Commun Signal 2018;16(1):49.

13) Ratei R, Hummel M, Anagnostopoulos I, Jähne D, Arnold R, Dörken $\mathrm{B}$, et al. Common clonal origin of an acute B-lymphoblastic leukemia and a Langerhans' cell sarcoma: Evidence for hematopoietic plasticity. Haematologica 2010;95(9):1461-6.

14) Chung WD, Im SA, Chung NG, Park GS. Langerhans cell sarcoma in two young children: Imaging findings on initial presentation and recurrence. Korean J Radiol 2013;14(3):520-4.

15) Mourah S, Lorillon G, Meignin V, Vercellino L, de Margerie-Mellon C, Pages C, et al. Dramatic transient improvement of metastatic BRAF(V600E)-mutated Langerhans cell sarcoma under treatment with dabrafenib. Blood 2015;126(24):2649-52. 